\title{
Analysis of the Offering and Resale Prices on the Second-Hand Skidders Market
}

\author{
Mario Šporčić ${ }^{1}$, Marijan Šušnjar ${ }^{1}$, Zdravko Pandur $^{1, *}$, Marin Bačić ${ }^{1}$, David Mijoč ${ }^{2}$ and Matija Landekić ${ }^{1}$ \\ 1 Department of Forest Engineering, Faculty of Forestry and Wood Technology, University of Zagreb, \\ Svetošimunska cesta 23, 10000 Zagreb, Croatia; msporcic@sumfak.unizg.hr (M.Š.); \\ msusnjar@sumfak.unizg.hr (M.Š.); mbacic1@sumfak.unizg.hr (M.B.); mlandekic@sumfak.unizg.hr (M.L.) \\ 2 Hercegbosanske šume Ltd. Kupres, Splitska bb, BA-80320 Kupres, Bosnia and Herzegovina; \\ dmijoc@gmail.com \\ * Correspondence: zpandur@sumfak.unizg.hr
}

Citation: Šporčić, M.; Šušnjar, M.;

Pandur, Z.; Bačić, M.; Mijoč, D.;

Landekić, M. Analysis of the Offering and Resale Prices on the

Second-Hand Skidders Market.

Forests 2021, 12, 729. https://

doi.org/10.3390/f12060729

Academic Editor: Luis Diaz-Balteiro

Received: 30 April 2021

Accepted: 31 May 2021

Published: 3 June 2021

Publisher's Note: MDPI stays neutral with regard to jurisdictional claims in published maps and institutional affiliations.

Copyright: () 2021 by the authors. Licensee MDPI, Basel, Switzerland. This article is an open access article distributed under the terms and conditions of the Creative Commons Attribution (CC BY) license (https:// creativecommons.org/licenses/by/ $4.0 /)$.

\begin{abstract}
Skidders, as self-propelled machines designed to transport trees or parts of trees by trailing or dragging it from the woods to a landing area, are still extensively used as the main wood extraction equipment in most of the Europe and worldwide. The high price of new machines (and even higher for CTL technology) makes the second-hand skidder market very interesting and appealing, especially for small forest owners and forestry contractors. So, this paper reports on a survey of used skidders available for purchase on the European market. Up-to-date empirical data was gathered by the analysis of the offerings on the main online marketplaces, i.e., specialized websites. The study included skidder make and model, variation in their age, annual usage and resale prices. The survey identified a total of 163 second-hand skidders and the results pointed out the prevalence of small-size machines $(<110 \mathrm{~kW})$, the average annual use (after excluding 1 year old machines from calculation) of 863 hours per year and the average re-sale price of about 65,000 EUR. Skidders are most commonly re-sold at an age of 16 years and the calculated price models show that skidder age is a stronger predictor of their value, i.e., resale price, than the total machine working hours. In the concluding section, paper also includes some reflections on possible future trends and perspectives of skidding technology in forestry.
\end{abstract}

Keywords: harvesting; machinery; extraction; skidder; second-hand

\section{Introduction}

Despite today's growing presence and usage of modern CTL (Cut-to-length) forest machinery (harvesters and forwarders), in many regions and countries after motor-manual felling (chainsaws), extraction of wood is still being done by special forest wheel tractorsskidders. According to ISO standard 6814:2009 (Machinery for forestry-Mobile and selfpropelled machinery-Terms, definitions and classification), skidder is a self-propelled machine designed to transport trees or parts of trees by trailing or dragging. Extraction of wood by skidding is done with one end of the load lifted off the ground and resting on the rear end of the vehicle, while the other end of the load is dragged along the ground. Skidding is a frequently used form of primary transportation that requires the availability of enough power to drag logs from the woods to a landing area [1].

Main advantages of ground skidding, compared to other extraction systems in forestry are simple technology, short training requirement and low cost extraction system. However, disadvantages are tendency to cause the greatest environmental problems, high density of skid trails, limited by slope gradient and soil conditions [2].

Although there is debate on who produced the first skidder and as many claims as there are manufacturers, the beginnings of development and usage of first skidders are placed in North America in the early 1950s [3]. The first skidder in USA was produced already in 1951 and in 1954 the first skidder with articulated steering. In the Scandinavian 
countries, skidders have been in forestry practice since 1962, in Austria and Germany since 1964 and in Croatia since 1968 [4]. In the Soviet Union, skidders were introduced also in the 1950s [5].

Today, there are a number of different constructive types of skidders used around the world-winch, grapple and clambunk skidders [6]. The technical functions that a skidder may perform in the most complex cases, are quite similar to those described for the Central European cable yarding systems [7]. The transportation function common to all skidder types enables such elements as empty travel, stopping and positioning at the loading or winching area, moving the load to the landing site and stopping. The hoisting and handling functions, depending on the equipment available, i.e., skidder type, enable mainly partial lifting of the load before the loaded travel and the load lowering at the landing. The handling functions also support actions like load attachment releasing, log pilling at landing etc. Devices that enable the hoisting and handling functions are the cables powered by winches, hydraulically powered grapples and the cranes used for loading and unloading the clambunks. Winching functions are specific to the winch skidders and they refer to the cable pulling to the logs as well as mechanical cable pulling of the logs to the skidder [6].

In many countries and regions, skidders undeniably continue to be the main means for wood extraction. In southern Europe, hauling of wood by skidders (and adapted farm tractors) is the most common way of wood extraction [8]. In Croatian piedmont and mountain forests extraction of wood from shelterwood and selection felling is primarily done by skidders [9]. In Austria, the extraction of wood is also mainly carried out by skidders, while cable yarders are usually used on difficult and demanding terrains [10]. In Slovenia as well as in southern and central Italy, the most common means of extracting wood are modified farm tractors equipped for skidding [11,12]. According to Borz [6] skidders are, with exception of North European countries, still extensively used as the main wood extraction equipment in most of the Europe and worldwide.

The relevant scientific literature comprises many articles dealing with skidders and performance of skidding operations. Most of the published papers address the issue of skidding efficiency and performance indicators such as the productivity and time expenditure in direct relation with the practices and conditions in skidding operations. Performed studies encompass different variables related to the technology used (machine type, functions, nominal power), site and stand characteristics (species mix, average tree volume, slope), work organization (studied operations) and practice variables (skidding distance, winching distance, slope of skidding roads, winching slope, log volume, load volume and the number of logs per load) [13-17]. There are fewer articles, dealing with the skidders' economic life, annual usage, resale value, i.e., their operational, financial and market perspectives after being in use for several years. These studies are more common for modern CTL technology-harvesters and forwarders [18,19], but not for skidders. Depreciated forestry machines costing methods are usually based on their capital cost, predefined life expectancy, interest and insurance rates, repair and maintenance, utilization rate and labor [20-22] or propose an integrated methodological and scientific approach to cost used forestry machines, in general [23]. These articles, however, are not specific to skidders and in many instances lack empirical data.

In this paper, up-to-date empirical data will be provided on the second-hand skidders based on the analysis of the offerings on the main online marketplaces. Gathered skidder data included machine type and size, age, annual usage and price of the machinery offered for sale in Europe. The procurement of new forestry machinery represents a significant capital investment, much higher than the one required for the used equipment. These kinds of high investments are difficult to make even for large (state-owned) forest companies and especially for small forest holdings, private forest owners, forestry contractors, etc. In this sense, purchasing used machinery often represents a more plausible option for them, despite possibly doubtful operational value of machinery and the resale of used machinery makes interesting and lively part of the market. In Croatia, as in many other 
transition countries in central and eastern Europe in 1990s, for example, forestry contractors in many cases arose from state forest company employees who left the company, moved to entrepreneurship and bought off the used and depreciated machines from their former employer [24]. Today also, certain instruments and measures of the European agricultural fund for rural development (EAFRD) provide financial support for acquiring not only new but also used forest machines (in Croatia for machines under 5 years of age). In addition, actual standards and projects in forestry e.g., FSC Chain of Custody certification (FSC CoC), Certification of Forest Contractors (CeFCo) project by ENFE, FSC and NEPCon, intend to require that all those involved in forest harvesting are properly equipped and qualified. So, the goal of this study was to provide reliable data on the second-hand skidders available on the European market. Investigation included number, type and size of skidders, variation in their age, annual usage and resale prices. In this way, relationship was determined between resale price, skidder size, age and total skidder use.

\section{Materials and Methods}

The data presented in the paper were collected through sale advertisements published on several specialized websites, i.e., portals that hold the largest pool of data on machines used and sold in any of the European Countries. The websites in question represent the main international and regional online marketplaces that deal with used heavy machinery and transportation vehicles, including forestry equipment. Overall, 10 specialized websites were searched for sale offers on skidders (Table 1). The survey covered the European market and it was conducted in the spring 2020. The data collected included machine make and model, year of production, total use in machine hours and the selling price. Technical details were given for most of the advertised skidders and where information was lacking, it was collected from the manufacturer. The study included only purpose-built skidders and did not cover farm tractors modified for skidding. The collected data were entered into a worksheet database and to avoid duplicate observations, repeated entries were erased.

Table 1. List of data sources.

\begin{tabular}{cc}
\hline Specialised Website, Name & Internet Address \\
Mascus & http://www.mascus.co.uk/ (accessed on 7 April 2020) \\
Machine Finder & http://www.machinefinder.com/ (accessed on 10 April 2020) \\
Machinery Zone & http://www.machineryzone.eu/ (accessed on 10 April 2020) \\
Ritchie Bros. Auctioneers & https://www.rbauction.com/ (accessed on 4 May 2020) \\
Agriaffaires & http://www.agriaffaires.co.uk/ (accessed on 16 April 2020) \\
Njuškalo & http://www.njuskalo.hr/ (accessed on 29 April 2020) \\
My Little Salesman & http://www.mylittlesalesman.com/ (accessed on 7 May 2020) \\
Agropijaca & http://www.agropijaca.com/ (accessed on 29 April 2020) \\
Technik Boerse & http://technikboerse.com/ (accessed on 11 May 2020) \\
Market Book & http://www.marketbook.ca/ (accessed on 7 May 2020)
\end{tabular}

Gathered database contained a total of 163 skidders. Selling price, year of production and work hours were not given for 39 machines, while at least one of these facts was missing for 64 skidders. Machine make and model were recognizable for all entries and for 85 observed skidders all key indicators were available (make and model, age, work hours and price). The analysis of the gathered data included its descriptive statistics and the calculation of the skidder resale price in relation to their age and total machine working hours. Machines' annual use was estimated by dividing the total working hours by their years of age. The estimation of annual use did not include machines less than one year old, since the resulting figures are strongly affected by the exact month of manufacturing and putting the machine into actual use. Skidders were also categorized in different size classes by power and entries where relevant data were missing were excluded from certain calculations. In determining the significance of difference between certain groups of 
machines appropriate statistical tests were used (Shapiro-Wilk, Levene's, Kruskal-Wallis and Mann-Whitney U post hoc test).

\section{Results}

\subsection{Skidder Size, Age and Brand}

Manufacturers often categorize forest machines into size classes according to typical or potential usage in certain logging conditions. These categorizations are not definitive, as machines can be used in different conditions, but in general, large trees require heavy machines and in thinnings smaller machines are more agile and cause less damage to forest stand [19]. Spinelli et al. [25] categorize skidders according to engine power into three groups: small size (power under $110 \mathrm{~kW}$ ), medium size (power between 110 and $130 \mathrm{~kW}$ ) and larger size skidders (more than $130 \mathrm{~kW}$ ). By using such categorization, the data in this study show predominance of small-size machines (Table 2). Over half of all 163 skidders belong to power class below $110 \mathrm{~kW}(54 \%)$, while the smallest share is made up of medium-size skidders (17\%). A significant number of large skidders (29\%) indicate a definite interest in large, powerful machines that are often imported from North America. Such findings are in line with other similar studies $[25,26]$.

Table 2. Size, age and brand of the investigated skidders.

\begin{tabular}{|c|c|c|c|c|c|c|}
\hline \multirow{2}{*}{ Size Class } & \multirow{2}{*}{ Skidders, $N$} & \multicolumn{4}{|c|}{ Machine Age in Years, \% } & \multirow{2}{*}{ Leading Brands } \\
\hline & & $<10$ & $11-20$ & $21-30$ & $>30$ & \\
\hline $\begin{array}{c}\text { Small } \\
(<110 \mathrm{~kW})\end{array}$ & 57 & 12 & 28 & 44 & 16 & Timberjack (33\%) \\
\hline $\begin{array}{c}\text { Medium } \\
(110-130 \mathrm{~kW})\end{array}$ & 20 & 35 & 30 & 30 & 5 & $\begin{array}{l}\text { John Deere }(40 \%), \\
\text { Caterpillar }(30 \%)\end{array}$ \\
\hline $\begin{array}{c}\text { Large } \\
(>130 \mathrm{~kW})\end{array}$ & 44 & 70 & 25 & 5 & - & $\begin{array}{c}\text { Caterpillar }(36 \%), \\
\text { HSM }(18 \%)\end{array}$ \\
\hline Total & 121 & 37 & 27 & 27 & 8 & \\
\hline
\end{tabular}

The machine age is available for 121 skidders in the database. Most of them are under 10 years old (37\%). Machines from 11 to 20 and from 21 to 30 years of age have about the same proportion $(25 \%)$. Significantly smaller is the number of machines older than 30 years $(8 \%)$. It can also be observed that older machines (20 years and over) are more common among small-size skidders and that younger skidders (under 10 years) are more numerous in the large-size class. The average age of the skidders in the dataset was 16 years (Table 2). It should be noted that older machines (e.g., over 20 years of age) are often failing to fulfill the present safety standards and are prone to end up in non-specialized professional use.

The most popular brands across size classes are Timberjack, John Deere, Caterpillar and HSM (Table 2). Other manufacturers take up significantly smaller proportions and include brands like LKT, Kockum, Franklin, Ecotrac, etc. The results also showed the dominance of cable skidders over other skidder types (clambunk, grapple) what is supported by other similar studies [25].

\subsection{Total Work Hours, Annual Use and Resale Price}

The middle $50 \%$ of skidders advertised on the second-hand market are sold after working between 4546 and 11,636 h (interquartile range), while the average skidder is most often sold at about 8500 total work hours (Table 3). Regarding age of the skidders, middle $50 \%$ of machines are sold at an age varying between 7.5 years and 24.5 years (interquartile range). Most commonly skidders are put up for sale at 16 years of age, although some machines are placed on the market after over 40 years in service and more than 20,000 work hours (Table 3). 
Table 3. Descriptive statistics for use, age and resale price.

\begin{tabular}{ccccc}
\hline & $\begin{array}{c}\text { Total Use, } \\
\text { Machine Hours }\end{array}$ & $\begin{array}{c}\text { Machine Age, } \\
\text { Years }\end{array}$ & $\begin{array}{c}\text { Annual Use, } \\
\text { Machine Hours/Year }\end{array}$ & $\begin{array}{c}\text { Resale Price, } \\
\text { EUR }\end{array}$ \\
\hline Mean & 8494 & 16.0 & 863 & 64,725 \\
Std. Dev. & 5219 & 10.2 & 589 & 57,231 \\
Min & 100 & 1.0 & 9 & 5710 \\
Max & 20,243 & 43.0 & 2826 & 267,631 \\
Median & 8091 & 15.0 & 822 & 41,299 \\
Mode & 11,000 & 12.0 & 692 & 35,540 \\
IQR & 7090 & 17.0 & 791 & 74,556 \\
\hline
\end{tabular}

Annual use in machine hours per year was simply estimated by dividing the hours of total use by the years of age. The results show, after excluding 1 year old machines from calculation, that the average annual use of analyzed skidders was $863 \mathrm{~h} /$ year. The middle $50 \%$ of skidders in the database reach annual use between 468 and $1259 \mathrm{~h} /$ year (interquartile range). Few skidders generated an annual use of over $2800 \mathrm{~h} /$ year (Table 3).

The average resale price set in the skidder ads was 64,725 EUR. For the middle $50 \%$ of the machines, asked selling prices range from 27,447 EUR to 102,003 EUR (interquartile range). At the same time, the highest resale prices in the database reach more than 267,000 EUR (Table 3).

Regarding size classes and annual usage, most of the small-size skidders achieve up to 500 work hours annually, while the majority of large-size skidders reach between 1000 and $1500 \mathrm{~h}$ of annual use. Medium-size skidders are relatively evenly distributed across four arrays of annual usage (Figure 1). The average annual use of small skidders amounts to $473 \mathrm{~h}$ /year, medium skidders $946 \mathrm{~h}$ /year and large skidders to $1209 \mathrm{~h} /$ year. Since Shapiro-Wilk test proved that annual use of skidders in the database doesn't follow normal distribution ( $p$-value of 0.00 ) and Levene's test rejected the assumption of homogeneity of variance between data groups (small, medium and large-size) by machine hours per year variable $(\mathrm{F}=3.737 ; p=0.028)$, Kruskal-Wallis test was used to test the difference in annual use among three skidder groups (small, medium and large-size). The differences were found to be statistically significant with $c^{2}(2,90)=22.295, p=0.000$. By using the Mann-Whitney $\mathrm{U}$ post hoc test, it was determined that the mean annual use value in small-size group ( $\mathrm{M}=472.83 ; N=38)$ is significantly different from medium-size group $(\mathrm{M}=946.37 ; N=16)$ and large-size group $(\mathrm{M}=1209.42 ; N=39)$. Statistically significant difference was also determined between medium-size and large-size group.

The average resale prices in all size classes are, expectedly, the highest for the newest machines (aged between 1 and 10 years). The skidder size also partially corresponds to higher prices. The average price for the biggest skidders (in the first age group) was 128,472 EUR, while the smallest machines had the average price of 122,610 EUR (Figure 2). This difference is even more notable in skidders between 11 and 20 years of age, with price difference being 22,942 EUR. The average resale price of medium-size skidders does not follow this regularity. In the first two age groups it is lower than the price of small skidders, while with skidders between 20 and 30 years it is even higher than the price of large skidders. Regarding average price, Shapiro-Wilk test resulted with the $p$-value of 0.00 meaning that data is not well-modelled by a normal distribution. Levene's test also rejected the assumption of homogeneity of variance between data groups (small, medium and large-size) by average price variable $(\mathrm{F}=3.990 ; p=0.022)$. According to Kruskal-Wallis test statistically significant difference in average price was determined between three skidder groups (small, medium and large-size) $\left(c^{2}(2,79)=27.955, p=0.000\right)$. Mann-Whitney $\mathrm{U}$ post hoc test showed that the average price value in large-size group $(\mathrm{M}=108,760.06 ; N=35)$ is significantly different from small-size group $(\mathrm{M}=43,374.66$; $N=32)$ and medium-size group $(\mathrm{M}=67,216.73 ; N=15)$. Statistically significant difference was not determined between small and medium-size group. 


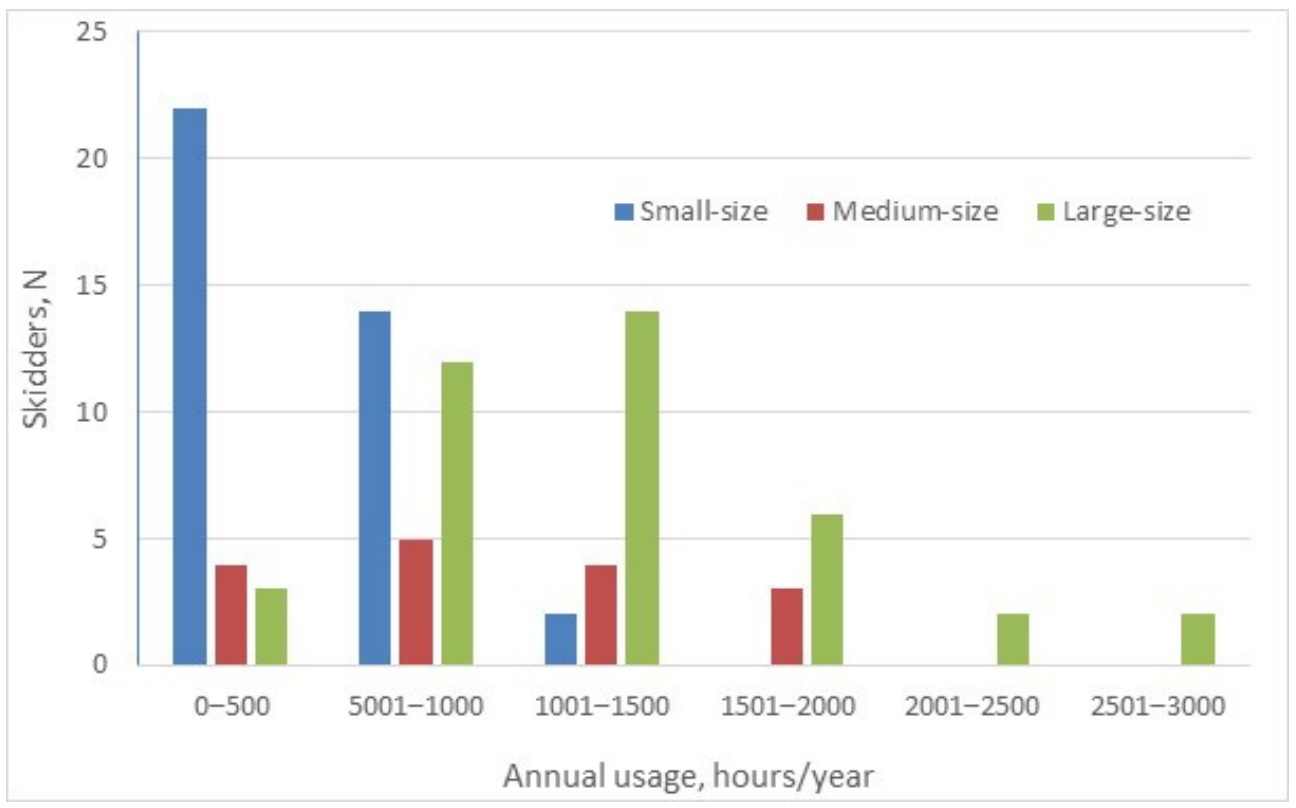

Figure 1. Annual use (machine hours per year) of skidders by size class.

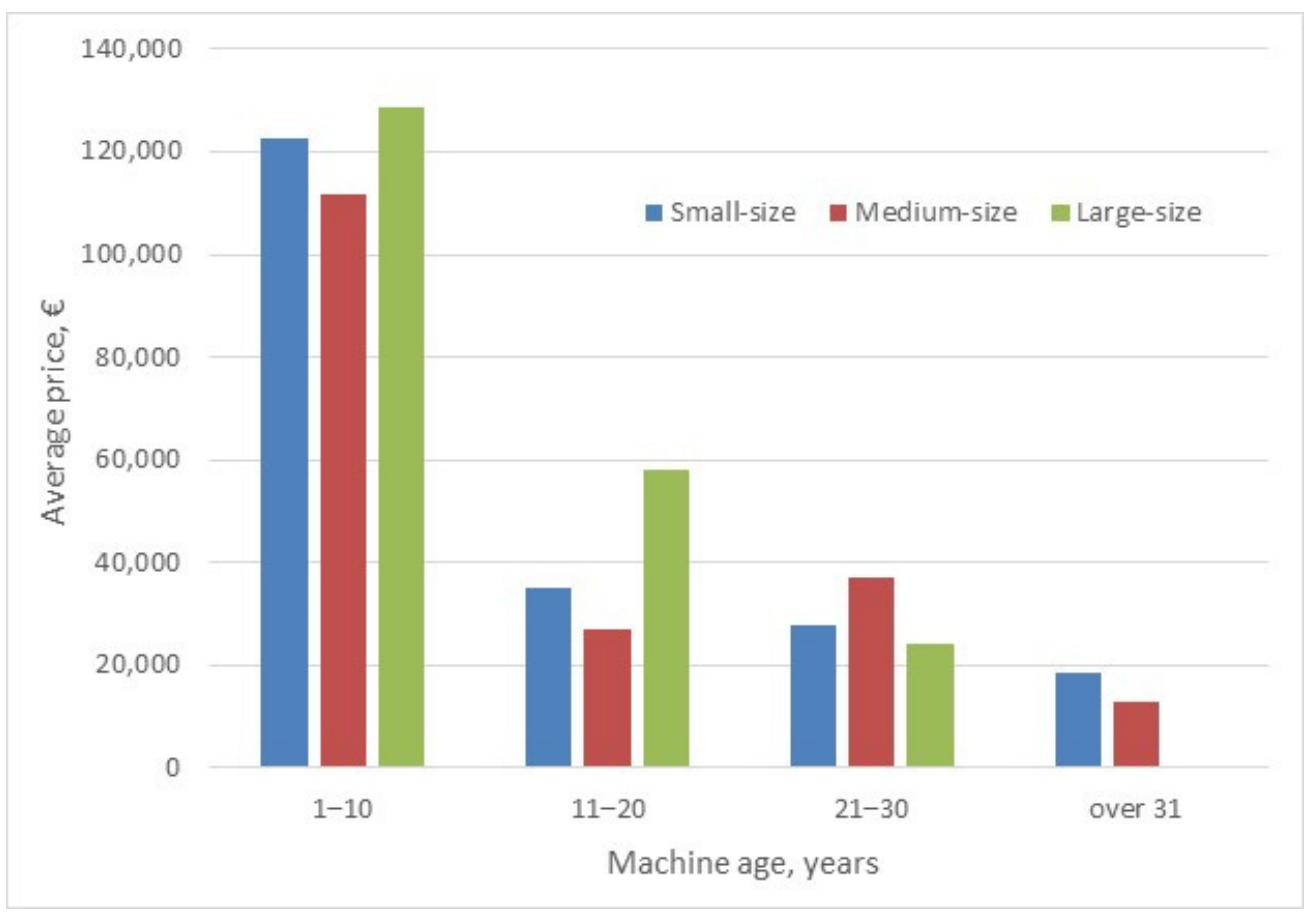

Figure 2. Average prices (EUR) of skidders by machine age and size class.

The resale price models for used skidders were calculated as a function of machine age (years) and total machine working hours (Figures 3 and 4). The regressions show that resale price of skidders is more dependent on the age of the skidders than their total use. According to the coefficient of determination, the age in years explains over $65 \%$ of the skidders' selling price (Figure 3), while the total use in machine working hours explains barely over $12 \%$ of skidder resale price (Figure 4 ). 


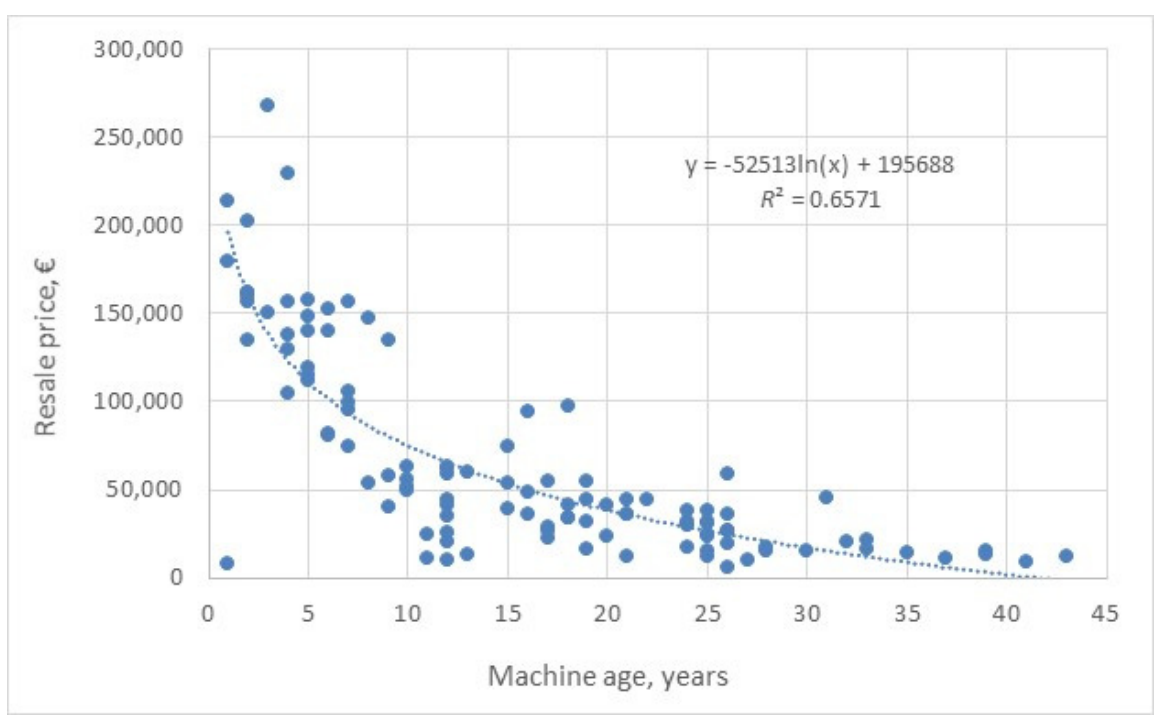

Figure 3. Relationship between skidder resale price and machine age.

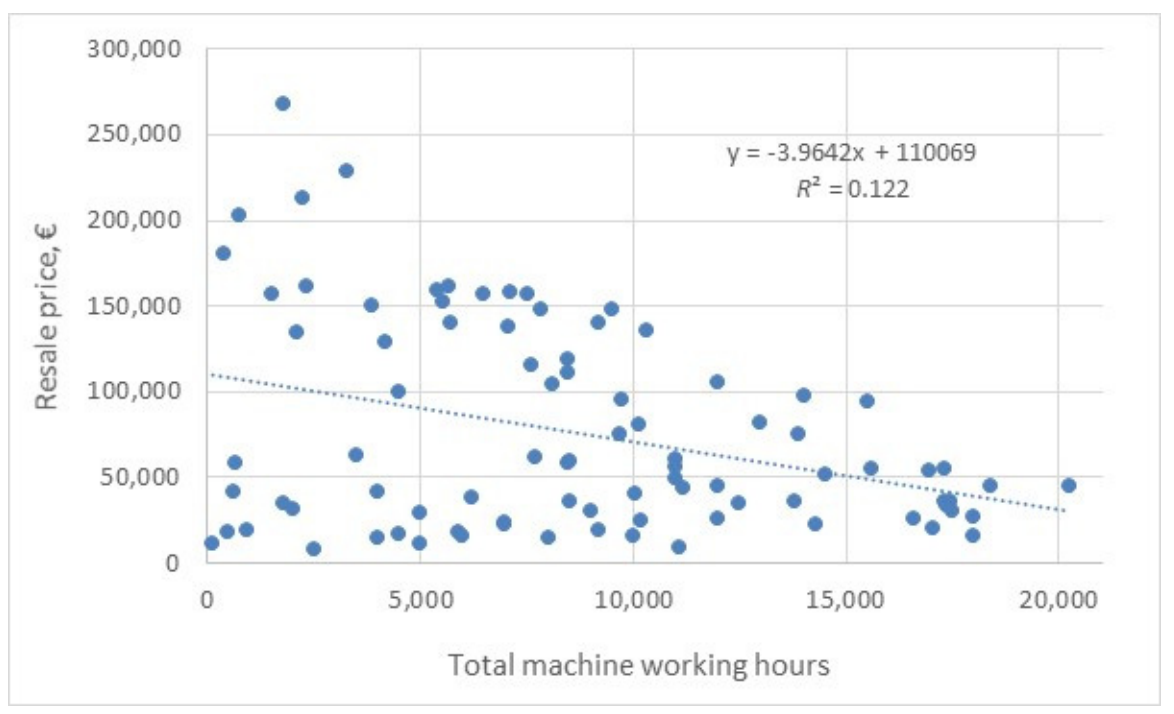

Figure 4. Relationship between skidder resale price and total machine working hours.

\section{Discussion and Conclusions}

In recent scientific literature skidding technology and equipment are receiving relatively little attention, especially when compared to CTL harvesting systems (harvesters and forwarders teamed up). CTL technology attracts more interest and is highly represented in various studies, technical literature, advertising and forestry machines fairs etc. However, although CTL dominates in Northern Europe, skidding still prevails in North America, as well as in much of Eastern Europe and in the Balkans [27]. Skidding is the dominant extraction system in Romania (90\% of total harvest), Bulgaria (80\%), Croatia and Czech Republic (70\%), Poland (50\%) and also Switzerland, an exception in Central Europe [25]. In addition, one of the scarce official surveys and papers on the subject, pointed out that the skidder fleet in Europe reckons a total number of 8370 machines at a minimum [25]. This certainly justifies interest towards skidding and the need for further research.

This paper reports on a survey of used skidders available for purchase in the European market. The survey identified a total of 163 second-hand skidders and provides up-todate empirical data on skidder type, age, annual use and resale prices. These data were obtained through the listings of main online marketplaces, i.e., websites and offer reliable 
parameters valuable for assessment of the second-hand skidders market and anyone interested in buying forest machinery.

The study covered only purpose-built skidders and did not include modified, forestryfitted farm tractors which are also often used for skidding in numerous countries. Farm tractors fitted for skidding do not have the same mobility and productivity as the dedicated skidders. Similar is with the ergonomic and safety standards what make them not so popular or even banned from logging operations in some countries [28].

The results of the study show that second-hand market offers skidders of all ages, ranging from nearly new to extremely old. Midspread (middle 50\%) of advertised skidders is varying between 7.5 years and 24.5 years and regarding 10-year age groups majority of skidders fall into the group under 10 years of age (37\%). The average machine is most commonly re-sold at 16 years of age.

Regarding size, i.e., skidder power classes, analyzes have confirmed that European loggers prefer smaller machines. Over half of all 163 skidders belong to power class below $110 \mathrm{~kW}(54 \%)$. However, there is a definite interest in large, powerful machines weighing well over $15 \mathrm{t}(29 \%$ of advertised skidders). Strong presence of large machines may reflect a general trend encountered with CTL harvesting leaning toward larger equipment as well $[29,30]$. A good insight into presence of skidder sizes can also be gleaned from the main European manufacturers (Camox, HSM, Welte) which all include heavy models $(>180 \mathrm{~kW}, 2 \mathrm{t})$ in their ranges [25].

The average annual use, after excluding 1 year old skidders, was 863 hours per year, with midspread from 468 to $1259 \mathrm{~h}$ /year (interquartile range). This is consistent with the results of other studies which point at usage rates between 600 and $1300 \mathrm{~h}$ per year [25]. In addition, bigger skidder size generally corresponds to a higher annual usage.

The resale prices are expectedly, the highest for the newest machines. The average skidder is most commonly re-sold at a price of about 65,000 EUR, while the highest selling prices for certain machines go even over 267,000 EUR. It should be noted that these are the asking prices set in the ads. The actual prices achieved for the sold machines may differ and they remain unknown. Calculated price models have also shown that skidder age is a stronger predictor of their value, i.e., resale price, than the total machine working hours. It explains more than $65 \%$ of the resale price.

This study shoes that despite the growing popularity of CTL technologies, skidders continue to have an important role in forest harvesting. Across many regions they continue to be the main wood extraction equipment and one of the most commonly used machines $[6,18,27]$. Second-hand skidder market also proves to be rich and vibrant with machines of different makes and models, ages, sizes and prices that are put up for sale. This is especially important and useful for small forest owners and forestry contractors who cannot afford to make high investments in new machinery. Some studies, in addition to that, point out that in replacement of the existing skidder fleet in Europe only $5 \%$ comes from new machine sales [25].

In conclusion, regarding possible future trends and perspectives of skidding technology, there are several issues that will continue to make skidders a common and viable extraction method. These are professionalization of forest work due to growing demands for logging services; abandonment of modified farm tractors and their replacement with purpose-built machines; possible certification of forest contractors in order to legitimately perform forest operations in FSC certified forests; terrain, legislation or financial limitations for more extensive use of CTL technology in many countries; increasing number of large-scale damaging storm events that needs salvaging. The above may even offer an opportunity for again expansion of skidding technology.

The results of this study provide valuable insight and guidance for all stakeholders in forest management, i.e., harvesting (contractors, decision-makers, forest holdings, private forest owners) regarding the acquisition of forest machines as well as the designing and implementation of policies aimed at encouraging the procurement of forest machinery and improving the level of technical equipment in forestry. 
Author Contributions: Conceptualization, M.Š. (Mario Šporčić) and M.Š. (Marijan Šušnjar); methodology, M.Š. (Mario Šporčić) and D.M.; software, M.L.; validation, M.Šs. (Mario Šporčić) and Z.P.; formal analysis, M.B.; investigation, M.Š. (Mario Šporčić) and D.M.; resources, M.Š. (Marijan Šušnjar); data curation, M.L.; writing - original draft preparation, M.Š. (Mario Šporčić); writing-review and editing, Z.P.; visualization, M.L.; supervision, M.Š. (Mario Šporčić) All authors have read and agreed to the published version of the manuscript.

Funding: This research received no external funding.

Data Availability Statement: The data used for the analysis in this study, are openly available on the marketplace websites i.e., internet addresses stated in the Table 1 (accessed from April to May 2020). Aggregated datasets are available from the authors upon reasonable request.

Conflicts of Interest: The authors declare no conflict of interest.

\section{References}

1. Grebner, D.L.; Bettinger, P.; Siry, J.P. Forest Harvesting Systems. In Introduction to Forestry and Natural Resources; Academic Press: Cambridge, MA, USA, 2013; pp. 287-302. [CrossRef]

2. Heinrich, R.; Arzberger, U. Forest operations in the tropics, reduced impact logging. Encycl. For. Sci. 2004, 247-252. [CrossRef]

3. Drushka, K.; Konttinen, H. Tracks in the Forest-The Evolution of Logging Machinery; Timberjack Group: Helsinky, Finland, 1997; 254p.

4. Šušnjar, M.; Oršanić, M.; Pentek, T.; Poršinsky, T.; Šporčić, M. Recent challenges of forest engineering academic education. Croat. J. For. Eng. 2013, 34, 167-172.

5. Blandon, P. Soviet Forest Industries, 1st ed.; Routledge: New York, NY, USA, 2019; 306p. [CrossRef]

6. Borz, S.A. A review of the Romanian and international practices in skidding operations. In Proceedings of the 14th World Forestry Congress, Durban, South Africa, 7-11 September 2015.

7. Heinimann, H.R.; Stampfer, K.; Loschek, J.; Caminada, L. Perspectives on central European cable yarding systems. In Proceedings of the International Mountain Logging and 11th Pacific Northwest Skyline Symposium, Seattle, WA, USA, 10-12 December 2001; pp. 268-279.

8. Spinelli, R.; Magagnotti, N. The effects of introducing modern technology on the financial, labour and energy performance of forest operations in the Italian Alps. For. Policy Econ. 2011, 13, 520-524. [CrossRef]

9. Horvat, D.; Zečić, Ž.; Šušnjar, M. Morphological characteristics and productivity of skidder ECOTRAC 120 V. Croat. J. For. Eng. 2007, 28, 11-25.

10. Russell, F.; Mortimer, D. A Review of Small-Scale Harvesting Systems in Use Worldwide and Their Potential Application in Irish Forestry; COFORD, National Council for Forest Research and Development: Dublin, Ireland, 2005; 48p.

11. Picchio, R.; Neri, F.; Sirna, A.; Spinelli, R. Improved winching technique to reduce logging damage. Ecol. Eng. 2012, 47, 83-86. [CrossRef]

12. Marenče, J.; Krč, J. Possibilities of using small tractors for forestry operations on private property. Croat. J. For. Eng. 2016, 37, 151-162.

13. Kluender, R.; Lortz, D.; McCoy, W.; Stokes, B.; Klepac, K. Productivity of rubber-tired skidders in southern pine forests. For. Prod. J. 1997, 47, 53-58.

14. Sabo, A.; Porsinsky, T. Skidding of fir roundwood by Timberjack 240 C from selective forests of Gorski Kotar. Croat. J. For. Eng. 2005, 26, 13-27.

15. Behjou, F.K. A techno-economic evaluation of skidding operation by Timber jack 450C and Clark Ranger 666BDS in Caspian forests. J. Food Agric. Environ. 2010, 8, 1020-1023.

16. Borz, S.A.; Ignea, G.; Popa, B. Assessing timber skidding efficiency in a group shelterwood system applied to a fir-beech stand. Afr. J. Agric. Res. 2014, 9, 160-167. [CrossRef]

17. Shegelman, I.R.; Budnik, P.V.; Baklagin, V.N. Simulation modeling of truck load of skidding tractors with a grapple for chokerless skidding. Croat. J. For. Eng. 2019, 40, 297-310. [CrossRef]

18. Spinelli, R.; Magagnotti, N.; Picchi, G. Annual use, economic life and residual value of cut-to-length harvesting machines. J. For. Econ. 2011, 17, 378-387. [CrossRef]

19. Malinen, J.; Laitila, J.; Väätäinen, K.; Viitamäki, K. Variation in age, annual usage and resale price of cut-to-length machinery in different regions of Europe. Int. J. For. Eng. 2016, 27, 95-102. [CrossRef]

20. Matthews, D.M. Cost Control in the Logging Industry; McGraw-Hill Book Co., Inc.: New York, NY, USA, 1942; 374p.

21. Miyata, E.S. Determining Fixed and Operating Costs of Logging Equipment; General Technical Report Nr. NC-55; Northern Central Forest Experiment Station, US Forest Service: St. Paul, MN, USA, 1980; 16p.

22. Ackerman, P.; Belbo, H.; Eliasson, L.; De Jong, A.; Lazdins, A.; Lyons, J. The COST model for calculation of forest operations costs. Int. J. For. Eng. 2014, 25, 75-81. [CrossRef]

23. Abbas, D.; Di Fulvio, F.; Marchi, E.; Spinelli, R.; Schmidt, M.; Bilek, T.; Han, H. A Proposal for an Integrated Methodological and Scientific Approach to Cost Used Forestry Machines. Croat. J. For. Eng. 2021, 42, 63-75. [CrossRef] 
24. Vondra, V.; Martinić, I.; Zdjelar, M. Procjena Uzroka Nerazvijenosti Privatnog Poduzetništva u Šumskom Gospodarstvu Hrvatske (Assessing the Causes of Underdevel-opment of Private Entrepreneurship in the Croatian Forestry); Research Study; Faculty of Forestry University of Zagreb: Zagreb, Croatia, 1997; 14p.

25. Spinelli, R.; Magagnotti, N.; Visser, R.; O’Neal, B. A survey of the skidder fleet of Central, Eastern and Southern Europe. Eur. J. For. Res. 2021, 11. [CrossRef]

26. Belenkji, J.; Andronov, A.; Martynov, B.; Khakhina, A. Trends of technical characteristics of wheeled skidding machinery. In Proceedings of the Conference Engineering for Rural Development, Jelgava, Latvia, 22-24 May 2019; pp. 662-668. [CrossRef]

27. Lundbäck, M.; Häggström, C.; Nordfell, T. Worldwide trends in the methods and systems for harvesting, extraction and transportation of roundwood. In Proceedings of the 6th International Forest Engineering Conference, Rotorua, New Zealand, 16-19 April 2018.

28. Harrill, H.; Visser, R. A Survey of NZ Ground-Based Harvesting Systems; HTN12; Forest Growers Research: Rotorua, New Zealand, 2019; 8p.

29. Arlinger, J.; Björheden, R.; Brunberg, T.; Lundström, H.; Möller, J.J. Size matters. Improving operations by analyzing the effects of machine size. In Proceedings of the Nordic Baltic Conference OSCAR14 SOLUTIONS for Sustainable Forestry Operations, NOVA Park Conference, Knivsta, Sweden, 25-27 June 2014; Volume 830, pp. 54-55.

30. Nordfell, T.; Öhman, E.; Lindroos, O.; Ager, B. The technical development of forwarders in Sweden between 1962 and 2012 and of sales between 1975 and 2017. Int. J. For. Eng. 2019, 30, 1-13. [CrossRef] 